Article

\title{
Brexit and the EU in Global Climate Governance
}

\author{
Claire Dupont ${ }^{1,2, *}$ and Brendan Moore ${ }^{3}$ \\ ${ }^{1}$ Department of Public Governance and Management, Ghent University, 9000 Ghent, Belgium; \\ E-Mail: claire.dupont@ugent.be \\ 2 Institute for European Studies, Vrije Universiteit Brussel, 1050 Brussels, Belgium \\ 3 Tyndall Centre for Climate Change Research, University of East Anglia, Norwich, NR4 7TJ, UK; \\ E-Mail: brendan.moore@uea.ac.uk \\ * Corresponding author
}

Submitted: 30 March 2019 | Accepted: 24 August 2019 | Published: 16 September 2019

\begin{abstract}
Climate change governance is one of the EU's priorities. The EU has developed a central (and arguably, a leading) role in global climate governance. The UK has been an important supporter of strong climate action both within the EU and in international climate negotiations. We investigate how/whether the EU's role in global climate governance will be affected by Brexit by focusing on potential changes in three conditions for EU leadership: (1) credible and ambitious internal climate policy; (2) constant and effective international engagement through climate diplomacy; and (3) the ability to attract followers. We find that the UK has sometimes played the role of a pivotal outlier, either pushing for more internal policy ambition or blocking certain policy options. Brexit is likely to have cumulative effects on the EU's role in global climate governance over the long term, through a series of changes in internal EU policymaking and climate diplomacy. The speed and scope of these changes depend on the nature of the future UK-EU relationship. We argue that the broader international context and strains on EU unity represent more urgent challenges to the EU's role in global climate governance than those posed by Brexit.
\end{abstract}

\section{Keywords}

Brexit; climate change; EU Emissions Trading System; European Union; leadership; UN climate negotiations; United Kingdom

\section{Issue}

This article is part of the issue "The Impact of Brexit on EU Policies", edited by Ferdi De Ville (Ghent University, Belgium) and Gabriel Siles-Brügge (University of Warwick, UK).

(C) 2019 by the authors; licensee Cogitatio (Lisbon, Portugal). This article is licensed under a Creative Commons Attribution 4.0 International License (CC BY).

\section{Introduction}

Climate change governance is one of the EU's priorities. The EU has adopted targets to reduce greenhouse gas (GHG) emissions, including a 40 per cent reduction by 2030 compared to 1990 levels, and has implemented a range of policies to achieve its goals. It has developed a central role in global climate governance through its climate diplomacy and by standing as an example of climate action. Indeed, the EU is often extolled for its climate leadership ambitions.

The UK has been an important supporter of strong climate action both within the EU and in international climate negotiations. It has been influential in strengthening EU policy ambition and in the choice of internal EU policy instruments. We are interested in investigating how/whether the EU's role in global climate governance will be affected by Brexit.

The article proceeds as follows: In the next section, we outline a framework for understanding the EU's role in global climate governance, building on leadership scholarship that highlights the importance of internal policy, external diplomacy and gaining followers for exerting leadership. We then examine the UK's role in both EU internal climate policy, focusing on the development of the EU Emissions Trading System (ETS), and in the inter- 
national climate negotiations. To do so, we draw on existing literature, document analysis, expert interview data and institutional voting statistics. We find that the UK has played an important role in EU climate policy and diplomacy, but that its role has gradually become less central over time. Next, we assess what these findings mean for the potential effect of Brexit on the EU's role in global climate governance. We find that changes after Brexit are likely to lead to cumulative effects over the long term, and that the speed and scale of change depends on the nature of the future UK-EU relationship. We argue that the EU faces other, more pressing challenges to its global climate role than Brexit, including the international climate context, EU internal unity and broader EU reform processes.

\section{Understanding the EU's Role in Global Climate Governance}

The EU has long aimed for international leadership on climate policy and governance (Bäckstrand \& Elgstrom, 2013; Oberthür \& Roche Kelly, 2008). It has managed to achieve a certain leadership status (Parker \& Karlsson, 2015), but the type and style of leadership shifted from rhetorical leadership in the 1990s, with little concrete policy action to follow up on stated commitments, to exemplary leadership in the late 2000s, with the adoption of domestic policy measures. The UK has been an international climate actor in its own right and also a contributor to EU global climate governance efforts. We seek to assess how Brexit could change the EU's role in global climate governance. For our analytical framework, we build on EU climate leadership literature.

What are the ingredients for climate leadership? Beyond the broader international political, economic and social context (Dalby, 2013; Dupont, Oberthür, \& Biedenkopf, 2018; Lockwood, 2018), three main conditions seem to be important for an international leadership role: (1) credible and ambitious internal climate policy; (2) constant and effective international engagement through climate diplomacy at multi-lateral and bi-lateral levels; and (3) the ability to attract followers (Wurzel, Connelly, \& Liefferink, 2017).

First, ambitious internal climate policy can be understood in two ways: either as policy that is more ambitious than the next most ambitious actor in terms of expected reductions of GHG emissions; or as policy that is ambitious enough to help achieve the calls for limiting global temperature increase to well below $2^{\circ}$ Celsius, as outlined in Article 2 of the 2015 Paris Agreement (UN, 2015). Thus, the level of policy ambition depends on the benchmark. In addition, the credibility of climate policy also depends on its implementation and feasibility: There is no point agreeing on ambitious targets if they cannot be implemented. By meeting these two conditions (ambition and credibility), the EU's internal policy can serve as an 'example' to other jurisdictions.

Second, constant and effective international engagement through climate diplomacy means that the EU it- self has the capacity to emphasise climate governance at both the international, multilateral level, and in bilateral relations. What makes climate diplomacy effective often depends on the broader context, the external partner and the capabilities/room for manoeuvre of the negotiating parties. Certain aspects are nevertheless within the EU's control. Adelle, Biedenkopf and Torney (2018) lay out three strategies of EU external climate policy/diplomacy: engaging in dialogues and negotiations; altering utility calculations; and building the capacity of others to act. This implies that a high degree of EU consistency, capacity and willingness is required on several diplomatic fronts to achieve the desired result.

Third, exerting leadership at the global level implies that other parties are following suit. So far, literature on the EU's global role in climate governance has shown a limited number of 'followers', as few other jurisdictions have engaged in policy development to the same scale and scope as the EU (Kulovesi, 2012; Parker \& Karlsson, 2015; Torney, 2019). However, followership could also be conceived in terms of the diffusion of policy ideas/instruments from the EU (Jordan \& Huitema, 2014). While a particular policy ambition or instrument may not be exactly copied, this does not necessarily imply that EU climate leadership is unsuccessful. Policies and ambitions in other jurisdictions may have at least been inspired by the EU.

Before any of these conditions can be met, there is already an assumption that the EU is a single actor, capable of communicating a unified message on the global stage. Of course, the EU is not a single unit: it is a collection of member states and supranational institutions negotiating among themselves to reach decisions about the way forward for internal policy and external strategies in climate governance. For the EU to be considered a legitimate, unitary actor, Vogler (2017) suggests four conditions that ought to be met: autonomy, volition, negotiating capability, and the ability to deploy policy instruments. The EU has the capacity to act on each of these areas in global climate policy (Dupont, 2019), making it a legitimate actor according to these criteria.

How does the UK contribute to the EU's global climate role? Building on the discussion by De Ville and Siles-Brügge (2019), the UK has sometimes acted as a 'pivotal outlier' (see also Smith, 2019), sometimes as a 'liberal and awkward partner'. Whether the UK will continue to play these roles in the future is uncertain. But Brexit presents challenges to the EU's global role in climate governance. The challenges are expected to play out over the long term, and removing the UK from the EU's internal policy development and the EU's climate diplomacy is likely to result in changes in: (1) the credibility and ambition of EU internal policies; (2) the consistency and effectiveness of climate diplomacy; and (3) the ability to attract followers. The speed and scale of the changes (both to policy and to diplomacy) are likely to depend to a considerable extent on the nature of the future UK-EU relationship on climate governance. The 
closer the cooperation and alignment between the two, the smaller the divergences are likely to be. Even so, over the long term, we would expect to see cumulative effects of divergences-possibly the result of small, iterative, even unintended changes in institutional structures and actor behaviour (De Ville \& Siles-Brügge, 2019) as the UK adopts domestic climate legislation and the EU engages in its usual processes of internal policy development and climate diplomacy after Brexit.

\section{The UK in EU Climate Policy and Diplomacy}

The following empirical discussion focuses on two areas of EU climate governance: the EU ETS, and the EU's role in international climate negotiations. First, the ETS is a key policy of the EU, and has been a source of policy learning for other jurisdictions (Dupont et al., 2018; Jotzo \& Löschel, 2014). The ETS is simultaneously an internal policy mechanism by which the EU aims to achieve its GHG emission reduction goals, and an external governance tool held up as a model for other jurisdictions (Dupont et al., 2018). By delving into detail on the UK's role in the reform of the ETS, we reveal the potential for change, both in the instrument itself and in its role as a policy model. Our analysis focuses on ETS policy developments since 2009 , centred around raising the carbon price, rather than on the policy's original adoption or reforms made prior to the 2009 Copenhagen conference (see Section 3.2). We made this choice as Brexit is most likely to affect how the EU approaches more recent (and future) ETS-related policy questions. Second, we examine the international climate negotiations under the UN Framework Convention on Climate Change (UNFCCC), which remains the most important venue where the global community comes together to focus exclusively on climate governance. The development of the EU's role in that forum, and the UK's role in that development, forms a key element of the EU's climate diplomacy.

Understanding the UK's role in these two areas is expected to reveal how Brexit could affect the EU's role in global climate governance. While the nature of the future UK-EU relationship is as yet unknown (at the time of writing), by identifying the UK's contribution to the EU's approach to climate governance, we can begin to unpack any repercussions from Brexit.

\subsection{The UK as a Supporter of EU Climate Policy}

The UK is widely seen as a well-informed and effective negotiator on climate and energy policy (Personal Communications, 2 December 2016 and 20 March 2019), both within the EU and in the preparations for international negotiations. These perceptions are in keeping with the UK's wider effectiveness and influence in multilateral governance institutions (Dee \& Smith, 2017). In general, the UK has supported strong EU climate policy and a clear leadership role in global climate governance (Rayner \& Jordan, 2017). The UK has repeatedly pushed for more stringent EU GHG emissions reduction targets. It supported increasing the $2020 \mathrm{GHG}$ target from 20 to 30 per cent (compared to 1990 levels) following the 2009 climate negotiations in Copenhagen. It also proposed a conditional 50 per cent EU GHG target for 2030 in preparation for the 2015 Paris Conference, and joined other member states to support an increase in the 2030 target above 40 per cent after the adoption of the 2015 Paris Agreement (Department of Energy and Climate Change [DECC], 2013; ENDS Europe, 2016).

But the UK did not support EU climate policy efforts across the board-it pushed for its own preferences on both EU GHG targets and on the choice of policy instruments. The EU's 2030 climate and energy framework includes targets for increasing the share of renewable energy (to at least 32 per cent) and for improving energy efficiency (by at least 32.5 per cent). In line with its focus on a 'one-target' policy discourse, the UK supported removing the 2030 renewables target completely, opposed a binding target when its proposal for removal failed, and argued for a flexible, indicative 2030 energy efficiency target (DECC, 2013, pp. 7-10; Fitch-Roy \& Fairbrass, 2018). Other historic examples show the UK's long-standing preference for a certain type of policy instrument (generally, market mechanisms rather than taxes and regulatory measures; see also De Ville \& SilesBrügge, 2019; Roederer-Rynning \& Matthews, 2019). In the 1990s, the UK repeatedly blocked the adoption of the $1992 \mathrm{EU} \mathrm{CO}_{2}$ /energy tax proposal in the Council of the EU (Rayner \& Jordan, 2011; Walker, 1993). The proposal was eventually abandoned, with several member states opposing it, and policymaking focused on other approaches, especially on the ETS.

\subsection{The UK and the EU ETS}

The EU ETS contributes to the EU's overarching goals to reduce GHG emissions by 20 per cent by 2020 and by 40 per cent by 2030 . The overarching EU GHG target is used to determine the emissions reductions in both the EU ETS, covering approximately 45 per cent of emissions, and the Effort Sharing Regulation, covering the remainder.

The ETS is a cap-and-trade system which sets a limit (the cap) on the EU's GHG emissions from electricity generation, intra-EU aviation, and energy-intensive industries such as steel, cement, oil refining, and pulp/paper production. In 2018, this cap was set at 1.93 billion tonnes of GHGs, mostly carbon dioxide. The cap is automatically reduced by 1.74 per cent per year from 2013 to 2020 and by 2.2 per cent per year afterwards. For each tonne of emissions allowed under the overall cap, the EU allocates emission allowances directly to ETS sectors and through auctioning. One allowance must be surrendered for each tonne of GHGs emitted. Each allowance can be traded between organisations at the price determined by the market (the carbon price or emission allowances price). Most revenues from auctioning are transferred to member state governments. 
In this section, we examine the UK's role in the reform of this instrument, looking at the UK government's role in the Council and the role of UK members of the European Parliament (EP). We also discuss the UK in the Commission, while acknowledging the Commission's character as a supranational institution. The UK played a key role in the adoption and reform of the ETS, and its exit from the EU is likely to change related policy dynamics (and thus also the contribution of the ETS to the EU'S role in global climate governance).

\subsubsection{The UK in the Council}

Since 2010, the UK government has consistently supported a policy discourse centred on a 'technologyneutral' approach to climate mitigation in the Council of the EU and the European Council. This approach gives a prominent role to the EU ETS and effort sharing in achieving climate mitigation goals (the 'one-target approach', see Fitch-Roy \& Fairbrass, 2018). The UK's support for the ETS also stems from it having long been a strong proponent of market-based instruments (Würzel, 2008; see also Roederer-Rynning \& Matthews, 2019). However, its wish to make the ETS and the GHG target the centre of internal EU climate policy has been complicated by low carbon prices in the ETS driven by the European economic crisis, and widespread resulting perceptions that the ETS is failing to spur decarbonisation. The UK has therefore been a key supporter of efforts to raise ETS carbon prices (Jevnaker \& Wettestad, 2017, p. 112; Wettestad \& Jevnaker, 2019, p. 120).

From May 2009 to March 2018, raising allowance prices was a key focus of ETS policy making. Prices dropped from $€ 30$ in June 2008 to below $€ 10$ between 2011 and 2018, with a low of $€ 3$ in April 2013. This was caused in large part by the economic crisis from 2008, which reduced emissions from ETS sectors. The resulting allowance surplus (unused allowances) amounted to 2.1 billion allowances in 2013 (European Commission, 2018, p. 29). The surplus reduced scarcity, leading to a reduction in prices. Proposals to intervene directly in the market to raise prices-by, for example, setting a 'price floor' that would set a minimum price-gained limited support from the EU institutions (Personal Communications, 23 March 2017 and 31 March 2017). As a result, for actors that supported raising allowance prices-including the UK-attention focused on volume management, or, the reduction of the number of allowances in circulation.

There were three major responses related to volume management in the ETS from 2009 to 2018: backloading, adopted in 2013, delayed the auctioning of 900 million allowances until 2019-2020; the Market Stability Reserve (MSR), adopted in 2015, automatically removed allowances equal to 12 per cent of the allowance surplus the prior year (including the backloaded allowances); and changes in the MSR, adopted in 2018, doubled the percentage of allowances to be removed to 24 per cent until 2023 and created a process to cancel allowances in the reserve starting in 2024 (Jevnaker \& Wettestad, 2017; Wettestad \& Jevnaker, 2019).

The UK Government supported all three legislative approaches to manage allowance volumes, as demonstrated by the UK's position in final Council votes on the Backloading Decision, MSR Decision, and 2018 Directive, and the UK's position in the contentious general approach agreed in February 2017 in preparation for trilogues with the EP on the 2018 Directive. The UK's proposals sometimes went even farther than those of their allies. For example, during the Backloading Decision debates, the UK Government proposed that the backloaded allowances be cancelled instead of delayed. It was also the only member state that pushed for a conditional 50 per cent GHG target for 2030 in the European Council, which would have reduced the ETS cap further.

ETS legislation has so far been adopted in the Council with a significant majority. If the UK had not participated in these votes, the legislation would still have been adopted. However, looking only at the final votes ignores the UK's leadership role in pushing for volume management proposals in the Council. For example, during the negotiations for the 2018 Directive, the UK played an important role in the core group of volume-management supporters (known as the like-minded group) consisting of the UK, the Netherlands, France, Sweden, Denmark, and Luxembourg (Personal Communications, 20 March 2017 and 29 March 2017). Another group of member states voted against both the final MSR Decision (because they felt it was too stringent) and the 2018 Directive general approach (in response to the volumemanagement provisions, especially cancellation). These volume-management sceptics were Poland, Hungary, Romania, Bulgaria, and Cyprus. During 2018, the likeminded group represented 35 per cent of the EU's population, compared to the volume-management sceptics at 15 per cent (Eurostat, 2019). The like-minded group had 32.3 per cent of Council votes versus 14.9 per cent for the volume-management sceptics. Without the UK, the gap in voting power between the two groups would be reduced to 5.3 percentage points (Council of the EU, 2018).

\subsubsection{The UK in the EP}

The UK delegation in the EP is highly fragmented on issues related to the ETS and volume management. Using the Hix-Noury-Roland formula for party cohesion (Hix, Noury, \& Roland, 2007), VoteWatch Europe has calculated party and member state cohesion for the MSR Decision and the 2018 Directive (VoteWatch Europe, 2015, 2018). The UK's cohesion was 52 (out of a maximum of 100) for the MSR Decision (ranked 21 out of 28 member states) and 53 for the 2018 Directive (ranked 9, with many member states having lower cohesion).

This contrasts with, and is in part due to, high levels of cohesion within UK party groups. Of the ten UK political parties in the EP, all but the Conservatives (European Conservatives and Reformists) and Labour (Progressive 
Alliance of Socialists and Democrats) had 100 per cent cohesion during the votes on the MSR and the 2018 Directive. The Conservatives (cohesion score of 82 for both the MSR and the 2018 Directive) and Labour (100 for the MSR, 84 for the 2018 Directive) were still highly cohesive on the final votes. The lack of cohesiveness for the UK overall is because these highly cohesive party groups voted in different directions. All UK parties except for the UK Independence Party voted for the MSR Decision, while six parties overwhelmingly voted for the 2018 Directive and four overwhelmingly voted against or abstained.

This has also meant that UK representatives in the Council and Parliament have often had difficulty coordinating. For example, an initial vote on backloading in the Parliament in April 2013 led to its (narrow and temporary) rejection. During that vote, 20 of the 24 Conservative members of the EP voted against backloading, despite the fact that the UK Government, led by their political party, strongly supported the measure (ENDS Report, 2013).

\subsubsection{The UK in the European Commission}

The European Commission has been a central policy actor in the adoption and subsequent reform of the ETS (Skjærseth, 2017; Skjærseth \& Wettestad, 2010). The Commission holds the right to initiate legislative proposals. In climate policy, prompts for a policy initiative have frequently flowed from the European Council. In this way, UK national preferences (e.g., on choice of policy instrument) can be passed to the Commission. Unlike in the Council and the Parliament, Commisson officials represent the EU, not their member state. Commission officials from the UK in the Directorate-General for the Environment and (from 2010) the Directorate-General for Climate Action have played key roles, including coordinating the original 2003 ETS Directive and the important centralising reforms under the 2009 Directive, as well as more recent roles in the Cabinet of the Climate Commissioner (Delbeke et al., 2006; Personal Communications, 18 May 2016 and 20 May 2016). While Dehousse and Thompson (2012) found that some Commission officials hold 'intergovernmentalist' views, namely that member states are ultimately in the lead of European integration processes, such views do not mean these officials (can) promote national interests in policy design. It is, therefore, difficult to isolate a particular influence on the Commision via UK nationals working there. At the time of writing, uncertainty persists about whether officials of British nationality will remain in the Commission after Brexit (e.g., Tamma, 2018).

\subsection{The UK and the EU's Role in International Climate Negotiations}

In 2019, the EU remains a key actor in the international climate negotiations. The EU has consistently engaged in efforts to push UNFCCC Parties to adopt strong climate targets and credible policy measures since the early 1990s. It has regularly been described as a leader in the international negotiations, both for its capacity to broker compromise (a capacity that has expanded since its disappointing performance during the 2009 Copenhagen negotiations) and to lead by example through its own policymaking (Bäckstrand \& Elgström, 2013; Groen \& Niemann, 2013; Wurzel et al., 2017). The UK has been an active player in the development of the EU's role in global climate governance. As with its role in internal climate policy, the UK has regularly pushed for ambitious global climate agreements, and it has been an important voice in the development of EU negotiating strategies (Rayner \& Jordan, 2017; Personal Communication, 20 March 2019). The history of the UK in the development of the EU's global role has not always been smooth sailing, but the general direction of UK influence has consistently been towards a strong, leading position.

In the 1990s, the EU was not the unified international actor we see today. It had little autonomy, volition, negotiating capability, or ability to deploy policy instruments (Vogler, 2017). In international climate negotiations, the EU relied on its member states to fill these gaps. An entrepreneurial Commission worked hard to advance internal policy (Collier, 1996; Pollack, 1994; Wettestad, 2005), and willing member states negotiated at the international level in the name of the EU. Contrary to the EU's slow climate diplomatic development, the UK was far more engaged in the process leading to the adoption of the UNFCCC in the late 1980s and early 1990s (Rayner \& Jordan, 2011). Michael Howard, the UK's Environment Secretary at the time, has been credited with playing an important role in ensuring agreement on the UNFCCC in 1992 (Haigh, 1996; Rayner \& Jordan, 2011). Leading up to the adoption of the Kyoto Protocol in 1997, the EU stepped up its ambition. It demonstrated its engagement by adopting the most ambitious reduction target of all parties signed up to the Kyoto Protocol-namely to reduce its GHG emissions by eight per cent between 2008 and 2012, compared to 1990 levels. It took some time before the EU agreed on sufficient policies to implement its target (the early 2000s). While EU leadership in the 1990s is often characterised as 'rhetorical' (or aspirational), there was strong engagement from the UK (Oberthür \& Roche Kelly, 2008).

The 2000 s began with a setback in international climate governance when the US withdrew from the Kyoto Protocol in 2001. The EU and its member states stepped up to 'champion' the Protocol's entry into force and to focus more efforts on developing a credible leadership role. Internally, the EU adopted a suite of policy measures between 2000 and 2010, and agreed on its 20 per cent GHG target for 2020 in 2007 (European Council, 2007; Oberthür \& Pallemaerts, 2010). It also paid far more attention to increasing its effectiveness in international negotiations: by ensuring a unified message at the negotiations, coordinated among EU members; by building EU 
negotiating capacity; by developing a system of lead negotiators to ensure continuity; and by continuing to provide an 'example'. These efforts also stemmed from the experience, in 2000, of the UK's efforts to build bridges with the US. Rather than working with the EU to try to bring the US on board in climate governance, the UK bypassed the then French Presidency to reach out to the US at negotiations in the Hague (van Schaik, 2010). Towards the end of the decade, the EU faced a demoralising blow when the Copenhagen climate negotiations failed to adopt a new international agreement in 2009. This climate conference provided lessons for the EU in how to project its leadership ambitions, and to gain followers.

By the 2010s, the global climate governance context had changed. In terms of share of global GHG emissions, the two major players were the US and China: GHG emissions from these two countries alone accounted for about 40 per cent of global emissions (World Resources Institute, 2019). While these new 'climate geopolitics' did not deter the EU from taking action on climate change, they did provide pause for reflection and adaptation (Oberthür, 2016). Moving on from Copenhagen, we see a well-oiled EU negotiating machinery developing. The EU has a strong climate diplomacy practice, combining efforts at the negotiating table with bilateral diplomatic and capacity-building efforts (Dupont et al., 2018). It engages in coalition building with other parties before, during and after international negotiations. It agrees on a single message in preparation for the negotiations, and regularly calls for more ambition. By the time of the international negotiations in Paris 2015, the EU was well placed to build on the momentum of the previous years to support the 'high ambition coalition'. This coalition was key for the adoption in the Paris Agreement of the goal of ensuring that global temperature increase remains 'well below' $2^{\circ}$ Celsius (UN, 2015). The UK's role was as one member of the EU. While it played an important role in the internal negotiations on the EU's 2030 climate and energy framework (see above), it was less visible on the international stage. This is not unusual, as the EU has developed its role such that member states (usually) do not pursue separate negotiating strategies. The UK still plays an important role internationally because of its administrative and negotiating capacity, which assists the development of the EU's negotiating stance. The UK's international diplomatic network, and its history as a cooperative member of the UN and the UN Security Council (Dee \& Smith, 2017) has also allowed it to propagate the EU stance towards climate change in its own external relations.

\section{Changes in the EU's Role in Global Climate Governance after Brexit}

The UK has been important in the development of the EU's role in global climate governance. First, the UK's position in EU internal policymaking has usually been in favour of ambitious GHG emission reduction targets. While the
UK's preferred policy choice has not always been adopted (e.g., three targets were adopted instead of the UK's preferred one target approach for the 2030 climate and energy framework), the UK has certainly been instrumental in developing the ETS. The UK was a vocal opponent of the $\mathrm{CO}_{2}$ /energy tax proposal in the 1990s and was a key pusher of the ETS reforms. Second, the UK has been central to the development of EU capacity in international negotiations. The UK's diplomatic capacity, its permanent seat on the UN Security Council and its close diplomatic ties provide a solid platform for promoting climate action. As the EU improved its external diplomatic efforts, it drew on the UK's expertise until the EU became a more unified international actor (Vogler, 2017). The UK also played an important role in shaping the EU's negotiating strategy (Rayner \& Jordan, 2017; Personal Communication, 20 March 2019). As such, the UK acted as a 'pivotal outlier' on different occasions in climate governance: by pushing for more ambitious policies and negotiation outcomes, and by objecting to certain policy directions.

What then can we expect for the EU's role in global climate governance after Brexit? While the past is not an accurate predictor of the future, we reflect on the changes that have already occurred. We suggest that change is most likely to occur in a slow, but iterative fashion, which could lead to long-term divergence in policy ambition/direction and international positions between the UK and the EU. The extent of such a divergence is unclear, as it is likely to depend on the degree of cooperation and alignment that is sought in the future UK-EU relationship, the UK's own global ambitions and internal developments/reform within the EU (Falkner, 2016).

An immediate effect of Brexit, regardless of the future EU-UK relationship, is in the balance of interests in EU internal policymaking. The UK will no longer participate in decision making in the EU institutions. The effects of Brexit may be more pronounced in the Council, where the UK government votes as a unitary actor, than in the Parliament, where party fragmentation in the UK delegation and difficulties coordinating with the government have led to lower cohesion for the UK delegation. In the short to medium term, the UK Government's absence from the Council will weaken coalitions in favour of higher prices in the ETS, by reducing the size of the coalition championing these changes (the like-minded group), and by removing the UK as a voice for the most radical options.

If the UK and the EU remain closely connected in climate governance, by aligning policy and continuing to work together in international negotiations, we should expect no sudden change in the EU's global role. If the UK were to be a member of the European Economic Area, for example, it would remain in the ETS and several other EU climate policies. However, even under this scenario, there is still likely to be change over time. With an agreed exit deal, the UK may still only remain a member of the ETS until the end of the 2020 trading period (Twidale, 2019). Further, if the UK is not obliged to re- 
port to the European Commission on policy implementation, there is no reason why the UK would not ratchet up or down its own ambition, leading to divergence between the EU and the UK internal climate ambition (Burns, Gravey, Jordan, \& Zito, 2019). In June 2019, the UK adopted a 'net zero' GHG emissions target for 2050, sending a signal that strong climate action is a UK priority (UK Government, 2019). Given the role of the UK in pushing for ambitious policy on GHG emission reductions and on strengthening the ETS, we could imagine that EU climate policy may move forward less urgently, having lost the UK as an important advocate. Further, Brexit is likely to lead to painful internal discussions about the redistribution of efforts among the remaining 27 members to achieve the 2030 goals. In turn, the effects of policy divergence may temper the contribution of EU internal policy to upholding a credible leadership role in global governance. Divergence in international negotiations is also likely to result over time, as policy preferences internally in the EU affect its negotiating strategy internationally. Therefore, even with close alignment and cooperation, we would nevertheless expect the EU's role in global climate governance to change in the long term as a result of small but cumulative changes in its: (1) internal policy; (2) climate diplomacy; and (3) ability to attract followers.

If the UK and the EU were to part on acrimonious terms, the effects are likely to be felt sooner. An exit without a deal, which is an increasingly likely scenario at the time of writing, and a poor relationship between the EU and the UK more generally, would make it less likely that the two parties would work closely in international climate negotiations and in aligning their policies. At the international level, this would be felt in the EU by a sudden disconnect from the UK's diplomatic network and capacity. However, this effect is still expected to be small at first, as the EU's own network and capacity has been significantly strengthened over the years. Furthermore, within the context of group politics in UN settings, it may remain in the UK's interest to pursue close ties with the EU to amplify any joint message in climate negotiations (Dee \& Smith, 2017). In this scenario, the UK becomes one more party with whom the EU needs to negotiate, but there may not be any special partnership. Alignment is likely to be far more ad hoc. For internal policy, EU law on the ETS and other climate policies would immediately cease to apply to the UK, making short-term divergence more likely. Indeed, indications from the UK Government show its intention to leave the ETS and install a carbon tax as early as 4 November 2019, and to prepare its own ETS (if there is no deal). While this seems to show little appetite for alignment, the UK ETS may link with the EU ETS in the future (Twidale, 2019). Over the long term, whether there is a sudden departure without a deal, or a managed UK exit, there will regardless be cumulative effects: A sudden, no-deal exit will mean that these effects will likely be felt sooner.

How the EU and the UK will manage these changes remains to be seen, and will also likely depend on the na- ture of the future relationship. Under the first scenario of a cooperative future relationship, management strategies are less urgent. Cooperation and EU-UK diplomatic channels would remain open, and the divergence that occurs would likely be predictable and stepwise, making management planning feasible. An acrimonious and sudden Brexit pits the UK and EU into traditional international relations, where diplomatic channels based on EU membership are no longer guaranteed. This second scenario may lead to rivalry between the EU and the UK, which could result in 'rivalrous emulation' pushing the EU and UK towards ever higher levels of climate ambition through their competition for leadership status (Coetzee, 2018). The adoption of the UK's 2050 net-zero emissions target may provide a first glimpse of what this type of rivalry could entail. Or the rivalry could shift a focus away from climate issues to more traditional international relations concerns (security, trade), leading to a general lowering of ambition on both sides.

In both scenarios, the long-term effects of Brexit on the EU's role in global climate governance are more substantial than its short-term effects. Brexit is unlikely to immediately affect the three main conditions for the EU's leadership role in global climate governance overnight: (1) credible and ambitious internal climate policy; (2) constant and effective international engagement through climate diplomacy at multilateral and bilateral levels; (3) the ability to attract followers (Dupont et al., 2018; Wurzel et al., 2017). The institutional and decision-making structure of the EU ensures some continuity (Pollack, 2009).

Finally, it is important to note that the EU's future role in global climate governance will not develop in a vacuum. Brexit is only one factor that could change the dynamics of its role. Other parties (e.g., China, India, the US, and Brazil) and their relationship with the EU (and the UK) can play as significant a role (if not more so), in global climate governance (Schreurs, 2016). As the international context shifts, the EU without the UK may simply find itself a shrinking global actor, a position that is more dependent on the role taken up by other major emitters than on the relationship with the UK. Arguably, the urgent risk to EU leadership in global climate governance is more likely to stem from wider issues of EU unity than from Brexit (Skovgaard, 2014). In the June 2019 European Council meeting, for example, member states were unable to agree on the goal of achieving climate neutrality by 2050, with opposition from Czechia, Estonia, Hungary and Poland (European Council, 2019).

\section{Conclusion}

The EU's role in global climate governance is the result of decades of learning, capacity building, internal policy development and climate diplomacy. Throughout this time, the UK has been an important actor, both in terms of internal climate policy development and in terms of the EU's global climate role. It contributed to 
the agreement of EU climate targets and regularly supported more ambition. It blocked the adoption of an EU $\mathrm{CO}_{2}$ /energy tax, but pushed for the ETS. It called for a one-target approach to climate policy. And the UK has been a key player in the development, adoption and implementation of the EU's international climate negotiating strategy.

Brexit is expected to affect the EU's global climate role through cumulative changes that will play out over the long term. Without the UK, the fulfilment of the three main conditions for leadership are relatively unchanged in the short term. For the first condition-credible and ambitious internal climate policy-Brexit will not now change the policy choices and targets adopted by the EU to 2030, although the issue of implementation after Brexit will need to be addressed. For condition two-constant and effective international engagement through climate diplomacy at multilateral and bilateral levels - the EU has developed good practices, experience and capabilities, although it may have to adapt to the loss of UK diplomats and negotiators. For condition threethe ability to attract followers-the EU's record has been relatively poor when it comes to others adopting strong targets, and it is hard to see how to Brexit would change that (for better or worse). However, the EU's policy portfolio is still a source of learning, and that is unlikely to change suddenly after Brexit.

Instead, the cumulative effect of changes in policy preferences, negotiation strategy, ambition, and diplomacy efforts are likely to lead to growing divergence between the UK and the EU on climate governance in the long term. Whether this results in a situation of rivalrous emulation (Coetzee, 2018) where the EU and UK try to outdo each other on effective climate governance, or results in a downgrading of ambition and leadership in climate governance, depends on a wide range of factors, including the international context and EU unity. However, the continuity provided by the EU's decision-making and institutional structure may reduce the risk of drastic and sudden changes to the EU's role in global climate governance after Brexit.

\section{Acknowledgments}

We would like to thank Ferdi De Ville, Gabriel SilesBrügge, and the participants in an authors' workshop that took place at Ghent University on 17-18 January 2019 for their very helpful feedback. We would also like to thank three anonymous reviewers for their excellent suggestions, and Charlotte Burns for inspiring the idea of 'rivalrous emulation'. Brendan Moore acknowledges funding from the COST INOGOV network (Innovations in Climate Governance, IS1309), which contributed to this research.

\section{Conflict of Interests}

The authors declare no conflict of interests.

\section{References}

Adelle, C., Biedenkopf, K., \& Torney, D. (Eds.). (2018). European Union external environmental policy: Rules, regulations and governance beyond borders. London: Palgrave MacMillan.

Bäckstrand, K., \& Elgström, O. (2013). The EU's role in climate change negotiations: From leader to 'leadiator'. Journal of European Public Policy, 20(10), 1369-1386.

Burns, C., Gravey, V., Jordan, A., \& Zito, A. (2019). De-Europeanising or disengaging? EU environmental policy and Brexit. Environmental Politics, 28(2), 271-292.

Coetzee, E. (2018). No rest for the weary: Competition and emulation in international politics. A Waltzian perspective. Politikon: South African Journal of Political Studies, 46(1), 1-19.

Collier, U. (1996). The European Union's climate change policy: Limiting emissions or limiting powers? Journal of European Public Policy, 3(1), 122-138.

Council of the European Union. (2018). Voting calculator. Council of the European Union. Retrieved from http://www.consilium.europa.eu/en/council-eu/ voting-system/voting-calculator/

Dalby, S. (2013). The geopolitics of climate change. Political Geography, 37, 38-47.

De Ville, F., \& Siles-Brügge, G. (2019). The impact of Brexit on EU policies. Politics and Governance, 7(3), 1-6.

Dee, M., \& Smith, K. E. (2017). UK diplomacy at the UN after Brexit: Challenges and opportunities. The British Journal of Politics and International Relations, 19(3), 527-542.

Dehousse, R., \& Thompson, A. (2012). Intergovernmentalists in the Commission: Foxes in the henhouse? Journal of European Integration, 34(2), 113-132.

Delbeke, J., Hartridge, O., Lefevere, J. G., Meadows, D., Runge-Metzger, A., Slingenberg, Y., . . . Zapfel, P. (2006). EU environmental law: The EU greenhouse gas Emissions Trading Scheme. Deventer, NL: Claeys \& Casteels.

Department of Energy and Climate Change. (2013). A 2030 framework for climate and energy policies: UK government response to Commission Green Paper COM(2013) 169 final (13D/171). London: Department of Energy and Climate Change. Retrieved from https://assets.publishing.service.gov.uk/government/ uploads/system/uploads/attachment_data/file/ 210659/130703_response_for_publication.pdf

Dupont, C. (2019). The EU's collective securitisation of climate change. West European Politics, 42(2), 369-390.

Dupont, C., Oberthür, S., \& Biedenkopf, K. (2018). Climate change: Adapting to evolving internal and external dynamics. In C. Adelle, K. Biedenkopf, \& D. Torney (Eds.), European Union external environmental policy: Rules, regulations and governance beyond borders 
(pp. 105-124). London: Palgrave MacMillan.

ENDS Europe. (2016). Countries call for stricter $2030 \mathrm{cli}-$ mate targets. ENDS Europe. Retrieved from https:// www.endseurope.com/article/45352/countries-callfor-stricter-2030-climate-targets

ENDS Report. (2013). Backloading rejection sends EU ETS into existential crisis. ENDS Report. Retrieved from http://www.endsreport.com/article/38480/ backloading-rejection-sends-eu-ets-into-existentialcrisis

European Commission. (2018). Report on the functioning of the European carbon market (COM[2018]842). Brussels: European Commission.

European Council. (2007). Brussels European Council 8/9 March 2007: Presidency conclusions (7224/1/07). Brussels: Council of the European Union. Retrieved from https://www.consilium.europa.eu/uedocs/ cms_data/docs/pressdata/en/ec/93135.pdf

European Council. (2019). European Council meeting (20 June 2019): Conclusions (EUCO 9/19). Retrieved from https://www.consilium.europa.eu/media/39922/ 20-21-euco-final-conclusions-en.pdf

Eurostat. (2019). Population on 1st January by age, sex and type of projection. EU Open Data Portal. Retrieved from http://data.europa.eu/euodp/data/ dataset/g33Nsv6Vud3AmmX9EJeOw

Falkner, G. (2016). The EU's problem-solving capacity and legitimacy in a crisis context: A virtuous or vicious circle? West European Politics, 39(5), 953-970.

Fitch-Roy, O., \& Fairbrass, J. (2018). Negotiating the EU's 2030 climate and energy framework: Agendas, ideas and European interest groups. London: Palgrave MacMillan.

Groen, L., \& Niemann, A. (2013). The European Union at the Copenhagen climate negotiations: A case of contested EU actorness and effectiveness. International Relations, 27(3), 308-324.

Haigh, N. (1996). Climate change policies and politics in the European Community. In T. O'Riordan \& J. Jäger (Eds.), Politics of climate change (pp. 155-186). London: Routledge.

Hix, S., Noury, A. G., \& Roland, G. (2007). Democratic politics in the European Parliament. Cambridge: Cambridge University Press.

Jevnaker, T., \& Wettestad, J. (2017). Ratcheting up carbon trade: The politics of reforming EU emissions trading. Global Environmental Politics, 17(2), 105-124.

Jordan, A., \& Huitema, D. (2014). Innovations in climate policy: The politics of invention, diffusion, and evaluation. Environmental Politics, 23(5), 715-734.

Jotzo, F., \& Löschel, A. (2014). Emissions trading in China: Emerging experiences and international lessons. Energy Policy, 75, 3-8.

Kulovesi, K. (2012). Climate change in EU external relations: Please follow my example (or I might force you). In E. Morgera (Ed.), The external environmental policy of the European Union (pp. 115-148). Cambridge:
Cambridge University Press.

Lockwood, M. (2018). Right-wing populism and the climate change agenda: Exploring the linkages. Environmental Politics, 27(4), 712-732.

Oberthür, S. (2016). Where to go from Paris? The European Union in climate geopolitics. Global Affairs, 2(2), 119-130.

Oberthür, S., \& Pallemaerts, M. (Eds.). (2010). The new climate policies of the European Union: Internal legislation and climate diplomacy. Brussels: VUB Press.

Oberthür, S., \& Roche Kelly, C. (2008). EU leadership in international climate policy: Achievements and challenges. The International Spectator, 43(3), 35-50.

Parker, C. F., \& Karlsson, C. (2015). Climate leadership. In K. Bäckstrand \& E. Lövbrand (Eds.), Research handbook on climate governance (pp. 191-201). Cheltenham: Edward Elgar.

Pollack, M. A. (1994). Creeping competence: The expanding agenda of the European Community. Journal of Public Policy, 14(2), 95-145.

Pollack, M. A. (2009). The new institutionalisms and European integration. In A. Wiener \& T. Diez (Eds.), European integration theory (2nd ed., pp. 125-143). Oxford: Oxford University Press.

Rayner, T., \& Jordan, A. (2011). The United Kingdom: A paradoxical leader? In R. K. W. Wurzel \& J. Connelly (Eds.), The European Union in international climate change politics (pp. 95-111). London: Routledge.

Rayner, T., \& Jordan, A. (2017). The United Kingdom: A record of leadership under threat. In R. K. W. Wurzel, J. Connelly, \& D. Liefferink (Eds.), The European Union in international climate change politics: Still taking a lead? (pp. 173-188). London: Routledge.

Roederer-Rynning, C., \& Matthews, A. (2019). What common agricultural policy after Brexit? Politics and Governance, $7(3), 40-50$.

Schreurs, M. (2016). The Paris Climate Agreement and the three largest emitters: China, the United States and the European Union. Politics and Governance, $4(3), 219-223$.

Skjærseth, J. B. (2017). The European Commission's shifting climate leadership. Global Environmental Politics, 17(2), 84-104.

Skjærseth, J. B., \& Wettestad, J. (2010). Making the EU Emissions Trading System: The European Commission as an entrepreneurial epistemic leader. Global Environmental Change, 20(2), 314-321.

Skovgaard, J. (2014). EU climate policy after the crisis. Environmental Politics, 23(1), 1-17.

Smith, M. (2019). The European Union and the global arena: In search of post-Brexit roles. Politics and Governance, $7(3), 83-92$.

Tamma, P. (2018). One year from Brexit, EU's British staffers in limbo. Politico. Retrieved from http://www. politico.eu/article/one-year-from-brexit-british-eustaffers-still-left-hanging/

Torney, D. (2019). Follow the leader? Conceptualising the relationship between leaders and followers in poly- 
centric climate governance. Environmental Politics, 28(1), 167-186.

Twidale, S. (2019). British carbon tax to start November 4 in the event of no-deal Brexit: Government. Reuters. Retrieved from https://uk.reuters.com/article/ukeu-britain-carbontrading/british-carbon-tax-tostart-november-4-in-the-event-of-no-deal-brexitgovernment-idUKKCN1U70NG

UK Government. (2019). The Climate Change Act 2008 (2050 target amendment) order 2019. Legislation.gov.uk. Retrieved from https://www. legislation.gov.uk/ukdsi/2019/9780111187654

United Nations. (2015). Paris Agreement. New York, NY: United Nations. Retrieved from https://unfccc.int/ sites/default/files/english_paris_agreement.pdf

van Schaik, L. (2010). The sustainability of the EU's model for climate diplomacy. In S. Oberthür \& M. Pallemaerts (Eds.), The new climate policies of the European Union: Internal legislation and climate diplomacy (pp. 251-280). Brussels: VUB Press.

Vogler, J. (2017). Global climate politics: Can the EU be an actor? In R. K. W. Wurzel, J. Connelly, \& D. Liefferink (Eds.), The European Union in international climate change politics: Still taking a lead? (pp. 20-33). London: Routledge.

VoteWatch Europe. (2015). Market stability reserve for the Union greenhouse gas emission trading scheme. VoteWatch Europe. Retrieved from http://www. votewatch.eu/en/term8-market-stability-reservefor-the-union-greenhouse-gas-emission-tradingscheme-draft-legislative-reso.html

VoteWatch Europe. (2018). Cost-effective emission reductions and low-carbon investments. VoteWatch Europe. Retrieved from http://www.votewatch.eu/ en/term8-cost-effective-emission-reductionsand-low-carbon-investments-draft-legislativeresolution-article-1-4.html

Walker, T. (1993). UK isolated over EC energy tax. The Times of London.

Wettestad, J. (2005). The making of the 2003 EU Emissions Trading Directive: An ultra-quick process due to entrepreneurial proficiency? Global Environmental Politics, 5(1), 1-23.

Wettestad, J., \& Jevnaker, T. (2019). Smokescreen politics? Ratcheting up EU emissions trading in 2017. Review of Policy Research, 1-25.

World Resources Institute. (2019). CAIT climate data explorer. Retrieved from https://cait.wri.org

Würzel, R. K. (2008). The politics of emissions trading in Britain and Germany. London: Anglo-German Foundation for the Study of Industrial Society.

Wurzel, R. K. W., Connelly, J., \& Liefferink, D. (Eds.). (2017). The European Union in international climate change politics: Still taking a lead? London: Routledge.

\section{About the Authors}

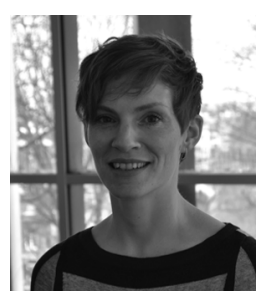

Claire Dupont is Assistant Professor of European and International Governance at Ghent University and Senior Associate Researcher at the Institute for European Studies, Vrije Universiteit Brussel. Her research focuses on EU climate policy and governance. She is the author of Climate Policy Integration into EU Energy Policy: Progress and Prospects (2016, Routledge) and co-editor (with Sebastian Oberthür) of Decarbonization in the European Union: Internal Policies and External Strategies (2015, Palgrave). She tweets under @Cladupont.

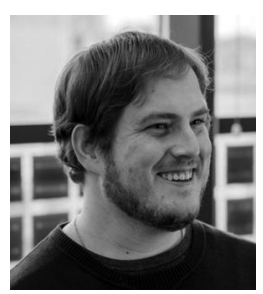

Brendan Moore (PhD) is Senior Research Associate at the Tyndall Centre for Climate Change Research, University of East Anglia. His research focuses on the EU ETS and European climate change policy. He is the co-author (with Andrew Jordan) of Durable by Design? Policy Feedback in a Changing Climate (forthcoming, Cambridge University Press). He tweets under @DrBrendanMoore. 


\section{COGITATIO}

Annex

\section{Personal Communications}

18 May 2016, European Commission official.

20 May 2016, European Commission official.

2 December 2016, European Commission official.

20 March 2017, member of a Permanent Representation to the EU.

23 March 2017, European Parliament staff member.

29 March 2017, member of a Permanent Representation to the EU.

31 March 2017, member of a Central and Eastern European Permanent Representation to the EU.

20 March 2019, member of a Permanent Representation to the EU. 